Agro-Science Journal of Tropical Agriculture, Food, Environment and Extension Volume 16 Number 2 (May 2017) pp. 9 - 16

ISSN 1119-7455

\title{
RISK MANAGEMENT AND DETERMINANTS OF FARM OUTPUT AMONG SMALL SCALE POULTRY FARMERS IN EKITI STATE, NIGERIA
}

\author{
Obike, K.C. Amusa, T.A. and Olowolafe, H.B. \\ Department of Agricultural Economics, Michael Okpara University of Agriculture, Umudike, P.M.B. \\ 7267 Umuahia, Abia State, Nigeria.
}

\begin{abstract}
The study was carried out to investigate risk management and determinants of farm output among small scale poultry farmers in Ekiti State, Nigeria. Cross sectional data were collected from randomly sampled 120 poultry farmers with the use of a well-structured questionnaire. The data collected were analysed using frequency, percentage, mean, chart and ordinary least square $(O L S)$ multiple regression analysis. The results of the study showed that production, financial, marketing, technological and human risks are the major sources of risks encountered by the poultry farmers. Disease outbreak, high cost of medication and vaccines, insufficient fund, lack of quality feed and fragility of poultry products are some of the risk situations in poultry farming in the study area. Risk management practices among the farmers are enterprise diversification, marketing and production strategies. The result of the multiple regression model $\left(R^{2}=0.96\right)$ revealed that age, household size, stock size, capital input, farming experience, location, cost of medication and cost of labour $(p<0.01)$ are the major determinant of farm output among poultry farmers.This shows that better risk management determines higher farm output. Based on the above findings, the study recommends that there should be adequate institutional supports in form of credits facilities, sales of day old chicks, quality feed, vaccines and drugs in government stores to poultry farmers for improved productivity.
\end{abstract}

Keywords: food security, risk management, poultry farming, small scale farmers, Ekiti State.

\section{INTRODUCTION}

Food production is of high importance for sustainable livelihood, economic productivity and food security of the developing countries (Obike $e t$ al., 2016). Food security involves access by all people at all times to enough food quality diet for active and healthy living. The report of FAO (2013) showed that Nigeria has an energy intake of $1730 \mathrm{Kcal}$ and an average protein supply of $64 \mathrm{~g}$ capita per day far below the $2500-3400 \mathrm{Kcal}$ minimum recommended daily intake. Similarly, Joseph and Ajayi (2002) stated that the recommended minimum nutrient requirements to be consumed per day per capita includes the 2191 Kcal and 65-86 g crude protein out of which at least $35 \mathrm{~g}$ or $(40 \%)$ must be animal protein. The present animal protein consumption in Nigeria is about $15 \mathrm{~g}$ per person per day which is relatively below the recommended 35g per person per day (Olarinde et al., 2010). This further aggravates the current wide spread hunger, malnutrition and stunted growth as well as increased spread of nutrition-related diseases in most parts of the country. Hence, there is need for increased production and consumption of animal-based protein for healthy living. Proteins of animal sources include fish, milk, beacon, pork, mutton, beef and poultry products such as eggs and poultry meat among others.

Poultry is an important sub-sector of the Nigerian livestock industry as it provides significant proportion of the needed animal protein to the populace as well as creating employment for a considerable percentage of the population (Bamiro et al., 2009). FAO (2010) reported that the poultry sub-sector comes fourth among sources of animal proteins for human consumption in Nigeria and contributes about $27 \%$ of the national meat production. Intensification of production of meat and eggs derived from prolific animals like poultry birds is relevant to meet animal protein requirements from domestic sources. Yusuf, et al, (2016) stated that poultry products such as meat and egg offer considerable potential for bridging the nutritional gap in view of the fact that high yielding exotic poultry are easily adaptable to our environment and the technology of production is relatively simple with returns on investment appreciably high. Apart from the nutritional significance of poultry products, the economic importance of poultry industry cannot be 
underestimated. The contribution of poultry production (meat and eggs) to total livestock output increased from $26 \%$ in 1995 to $27 \%$ in 1999 and it is presently put at about $42 \%$ (Bukunmi and Yusuf, 2015). This is because, relative to other groups of livestock such as rabbit, cattle, sheep and goat, poultry has the fastest rate of economic returns. In addition, poultry production can be carried out in a small area of land since the issue of land is a major problem of agriculture in most part of Nigeria (FAO, 2013). Commercial poultry production in Nigeria was estimated at about 800 million USD as at 2010 (NBS, 2012). FAO (2010) reported that poultry sub-sector contributed about $25 \%$ of the agricultural domestic products of the Nigerian economy. Socially, poultry meat and eggs are the most consumed animal proteins due to lack of religious or cultural discrimination against the products unlike pig, dog and some other livestock. Therefore, if the poultry industry is properly harnessed, it is capable of serving as a major source of foreign earnings to complement the present over-dependence on crude oil. Despite the acknowledged nutritional and socio-economic importance of poultry products, poultry production is grossly challenged with notable farming risk. Risk in farming enterprise is the danger of possible occurrence of injury, damage, loss or uncertainty that agricultural production will yield expected outcome or not. Jain and Parshad (2007) stated that farming risks is associated with the negative outcome that may stem from imperfectly predictable, biological, climatic and price variables. Njavro (2009) grouped risk sources in agribusiness enterprises into social, market, institutional, financial, production and foreign exchange risk. According to Olarinde, Manyong and Akintola (2010), risks associated with the farmers are categorised into (i) market risks (demand and supply) conditions, (ii) risk related to inflation and interest rates and (iii) production risk. Production risk occurs because agribusiness enterprise is affected by many uncontrollable events that are often related to weather such as unlimited rain or drought, diseases and pests (especially in poultry business), random physical hazards and technological failure of the production process (Akinola, 2014). Production, market and financial risk is the risk associated with adverse variation in yield due to bad weather, disease outbreak, insufficient and untimely supply of inputs, insufficient credit and inadequate processing facilities. Market risk is that borne when actual prices are different from that originally expected. Social risks refer to actions of human beings on the farm such as theft of produce, bush fire, invasion of farms while economic risks was identified as risk resulting from input and output price fluctuations which translate to low income (Effiong, et al., 2014). The use of debt in financing farm enterprise exposes farmers to financial risk. Alimi and Ayanwale (2005) noted that financial risk occurs when enterprise profitability (rate of return) is less than the cost of capital. Effiong, Enyenihi and George (2014) described other forms of farming risks to include natural risks which results from natural occurrences such as drought, flood, wind, storm, diseases and pests and they have adverse effect on output of agricultural production. Adubi (2000) noted that small scale farmers are more exposed to risk than other segments of the population because they exist at the margins of modern economy. Risk is an inherent feature of modern poultry production due to the complex and fragile nature of both the intermediate (day-old chicks) and poultry end products (meat and eggs). In Nigeria, Adepoju, Timothy and Oyekale (2013) observed that production activities of poultry farmers are characterized by high level of risks. These include high costs of inputs and veterinary services which reduces productivity and net returns from the investment. In some cases, outbreak of diseases could wipe out the entire population of birds in a poultry farm leading to the death of the business enterprise. Further, theft of birds and market glut could force the farmers to sell off their products below production costs. This leads to reduction in profit, limited access to formal financial systems for credit and insurance, negligible capital investment and low savings (Oparinde, 2008). Hence, risk management effort is important for sustainability of poultry farmers.

Risk management in poultry farming is extremely important because failure to manage farming risks has direct negative effects on farmers' income, market stability and potential food security. Abotsi, Dake and Agyepong (2014) described risk management as involving the use of risk assessment techniques to determine the initial level of risk and, if it is excessive, to develop a strategy to ameliorate the risks until the overall level of risk is reduced to an acceptable level. Vanany, et al., (2009) stated that understanding, identifying and assessing the risks based on probability of occurrence and severity of impact is a starting point to develop effective risk management strategies. Asogwa, et al.,(2014) however noted that three important risk management decisions in the farms include keeping debt low, producing at the lowest cost and good liquidity condition. Howell and Hazzard (2012) maintained that decision for managing risk starts 
with identifying the most crucial risk faced by farmers, understanding the potential impacts and likelihood of desirable outcomes, identifying and taking possible steps to lessen the impacts to avert failure. In Ekiti State, many of the existing poultry farms are folding up and prospective investors are becoming increasingly reluctant to invest in poultry farming due to the associated risks and uncertainties in poultry industry. This trend if not checked could gradually and eventually lead to collapse of the poultry industry in the state. The consequences of the failure of major stakeholders in poultry industry to rise up to the challenge of saving the industry could lead to a serious reduction in poultry production and shortage of protein intake of people. This according to Bamiro et al., (2009) could results into malnutrition, ill health, lower productivity and poor welfare of the farmers. This situation therefore justifies the need for a thorough assessment of existing risk management and determinants of poultry farming output. Hence, this study was carried out to empirically investigate major sources of risks in poultry farming, risk situation in poultry industry, risk management practices by farmers and determinants of farmers output in poultry farming using Ekiti State as a case study.

\section{MATERIALS AND METHODS \\ Study Area}

The study was carried out in Ekiti State, Southwest Nigeria. The state is located between longitude $4^{0} 5^{1}$ and $5^{0} 45^{1}$ East of the Greenwich and latitude $7^{0} 15^{1}$ and $8^{0} 5^{1}$ North of the equator. Ekiti State lies South of Kwara State and Kogi State, East of Osun State and West of Ondo State. Ekiti State has 16 administrative Local Government Areas. The state is broadly categorized into two agricultural zones: $\mathrm{A}$ and $\mathrm{B}$, based on agronomic and ecological consideration (Fakayode et al., 2008). Ekiti State has a climate marked by two major seasons which include raining season which last between April to October and the dry season lasting from November to March. The prevailing temperature of the state ranges between $21^{\circ} \mathrm{C}$ to $28^{\circ} \mathrm{C}$ with high humidity. The topography of the state is mainly an upland area, rising over 250metres above sea level (Ekiti State Government, 2008). The state has a projected population of 2,801,161 people as of 2011 (National Bureau of Statistics, 2012). Agriculture is the main occupation, providing income and employment for more than $75 \%$ of its population. The major cash crops grown in the state are cocoa, coffee, kolanut, cashew and oil palm. Arable crops grown are yam, cassava, maize, cowpea and cocoyam (Ekiti State Government, 2008). The major livestock reared in the state include poultry, pig, sheep and goat.

\section{Sampling and Data Collection}

Multi stage sampling technique was used in selecting respondents used for the study. The first stage involved purposive selection of the two Agricultural Development Programme (ADP) agricultural zones in the state which are Ido Osi and Ikole zones. The purposive selection of the two zones was due to the presence of poultry farmers across the zones. In the second stage, two Local Government Areas (LGAs) were randomly selected from each of the two agricultural zones giving total of four LGAs for the study. The third stage involved random selection of three communities from each of the four LGAs giving a total of 12 communities. In the fourth stage, ten poultry farmers were randomly selected from each of the 12 communities totaling 120 respondents (poultry farmers) that constituted the sample size for the study. The data for this study were collected from primary sources with the use of a structured questionnaire. The information that were collected from respondents includes socio-economic characteristics of the small scale poultry farmers, major sources of risk in poultry farming, risk situations, risk management practices adopted by the poultry farmers.

\section{Method of Data Analysis}

The data collected were analyzed using both descriptive and inferential statistics. For instance, descriptive statistics such as charts, frequency and percentage were used for addressing major sources of risk in poultry farming. Risk situation among the poultry farmers and risk management practices adopted by the poultry farmer were analyzed with mean using 5-point Likert scale. This was structured into Strongly Agree (SA), Agree (A), Undecided (UD), Disagree (D) and Strongly Disagree (SD) with corresponding values of 5, 4, 3, 2 and 1 respectively. The criteria reference or cutoff point was 3.00. Therefore, any risk situation or risk management practice with mean value of 3.00 and above was regarded as Agreed, otherwise Disagreed. The determinant of poultry farmer's output was realized using OLS multiple regression analysis. The model specification of the regression analysis is specified below:

$\mathrm{Y}=\mathrm{f}\left(\mathrm{X}_{1}, \mathrm{X}_{2}, \mathrm{X}_{3}, \mathrm{X}_{4}, \mathrm{X}_{5}, \mathrm{X}_{6}, \mathrm{X}_{7}, \mathrm{X}_{8}, \mathrm{X}_{9}, \mathrm{X}_{10}, \mathrm{X}_{11}\right.$, $\left.\mathrm{X}_{12}, \mathrm{X}_{13}, \mathrm{X}_{14}, \mathrm{ei}\right)$ 
$\mathrm{Y}=$ Output (Naira)

$\mathrm{X}_{1}=$ Age (years)

$\mathrm{X}_{2}=$ Gender $($ Male $=1$, Female $=0)$

$\mathrm{X}_{3}=$ Household size (number of persons)

$\mathrm{X}_{4}=$ Education (years of formal education)

$\mathrm{X}_{5}=$ Primary occupation $($ Farming $=1$ otherwise $=0$ )

$\mathrm{X}_{6}=$ Stock size (total number of birds)

$\mathrm{X}_{7}=$ Capital input (Naira)

$\mathrm{X}_{8}=$ Farming experience (years)

$\mathrm{X}_{9}=$ Membership of cooperative (being member= 1 , otherwise 0 )

$\mathrm{X}_{10}=$ Location $($ Urban $=1$, otherwise $=0)$

$\mathrm{X}_{11}=$ Cost of feed (Naira)

$\mathrm{X}_{12}=$ Cost of medication (Naira)

$\mathrm{X}_{13}=$ Cost of Labour (Naira)

$\mathrm{X}_{14}=$ Risk index (ratio of risk recorded by a farmer to total risks identified) $\mathrm{ei}=$ error term

The explicit form of the linear model is as follows:

$\mathrm{Yc}=\mathrm{b}_{0}+\mathrm{b}_{1} \mathrm{x}_{1}+\mathrm{b}_{2} \mathrm{x}_{2}+\mathrm{b}_{3} \mathrm{x}_{3}+\mathrm{b}_{4} \mathrm{x}_{4}+\mathrm{b}_{5} \mathrm{x}_{5}+\mathrm{b}_{6} \mathrm{x}_{6}+$ $\mathrm{b}_{7} \mathrm{x}_{7}+\mathrm{b}_{8} \mathrm{x}_{8}+\ldots \ldots \ldots . .+\mathrm{e}$

Four functional forms: linear, semi-log, double-log and exponential were estimated using the Ordinary Least Square (OLS). This was considered necessary in order to select the functional form with the best fit. In the semi-log and double log forms, 0 values in the dummies were replaced with 0.0001 . This is because, the number 0 is undefined for $\log$ (Amusa et al., 2011).

\section{RESULTS AND DISCUSSION}

\section{Major Sources of Risk in Poultry Farming}

Multiple responses of the percentage distribution of major sources of risks faced by poultry farmers in the study area is presented in figure 1 . From the figure, $100 \%$ of the farmers faced production risk, $97 \%$ faced financial risk, $88 \%$ faced marketing risk, about $82 \%$ faced technological risk while about $67 \%, 62 \%$ and $50 \%$ of the farmers faced human, causality and institutional risk respectively. The findings of this study agreed with that of Akinola (2014) who identified risk sources in poultry farming to include market, production, political (institutional), disease outbreak and financial risk among others. Olarinde, et al, (2010) noted that risks associated with the farm system's economic environment relate to uncertainty about market (demand and supply), inflation and interest rates (relevant to long-term planning) and production risk.

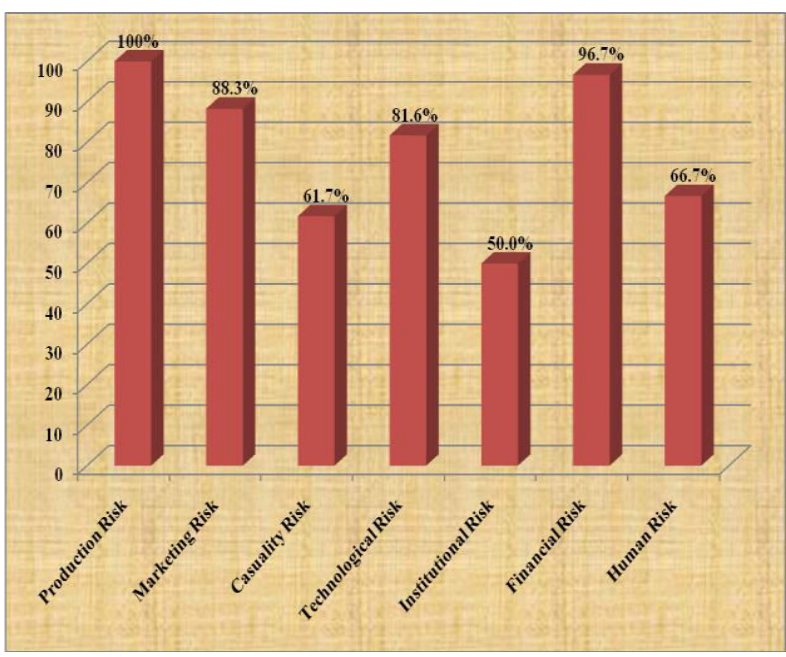

Figure 1: Bar Chart Showing Percentage Distribution of Major Sources of Risks Facing Poultry Farmers in Ekiti State.

Source: Field Survey, 2016.

\section{Risk Situation in Poultry Farming}

The result in Table 1 presents the risk situation in poultry farming in Ekiti State. Some indicators of risk situations in poultry farming in the area and their respective mean values include: frequent cases of disease outbreak (4.36), high cost of medication and vaccines where available (4.19), insufficient fund by most farmers (4.68), lack of quality feed for improved yield (4.13), unfavourable weather condition affecting poultry birds (3.98), fragility of poultry products such as eggs and day old chicks (4.57), lack of technical know-how of improved farming technologies by most farmers (4.32) and inadequate credit facilities for improved production (4.20) among others. This mean values of these indicators are greater than the cut-off point value of 3.00 on five point rating scale which indicate that the identified indicators are risk situations in poultry farming in Ekiti State. The findings of this study is in line with that of Effiong, et al, (2014) who identified the risks in poultry farming to include weather/climate, power failure, high mortality rate of birds, infestation of diseases, changes in input prices, poor and inadequate finance, attack by predators and poor storage facilities. Lawal, et al, (2009) reported that endemic diseases such as Newcastle and Gumboro are problems of poultry farming which however require reliable vaccines that are not often available to the farmers. 
Obike, K.C. Amusa, T.A. and Olowolafe, H.B.

Table 1: Mean ratings of the farmers on risk situations in poultry farming in the study area $(\mathrm{n}=120)$

\begin{tabular}{|c|c|c|c|c|}
\hline $\mathrm{SN}$ & Risk situation & $\bar{X}$ & SD & Rmks \\
\hline 1 & Frequent cases of disease outbreak & 4.36 & 0.67 & A \\
\hline 2 & Rise in cost of inputs & 3.84 & 0.47 & A \\
\hline 3 & High risk of theft & 3.39 & 0.70 & A \\
\hline 4 & Snake attack & 3.25 & 0.52 & A \\
\hline 5 & Lack of medication and vaccines for birds & 3.85 & 0.67 & A \\
\hline 6 & High cost of medication and vaccines where available & 4.19 & 0.46 & A \\
\hline 7 & Rise in cost of exotic breed & 2.68 & 0.57 & $\mathrm{D}$ \\
\hline 8 & Insufficient fund by most farmers & 4.68 & 0.46 & A \\
\hline 9 & Low demand for poultry products in demand & 2.44 & 0.57 & $\mathrm{D}$ \\
\hline 10 & Lack of quality feed for improved yield & 4.13 & 0.85 & A \\
\hline 11 & Unfavourable weather condition affecting poultry birds & 3.98 & 0.50 & A \\
\hline 12 & Unstable price of products in the market & 2.60 & 0.80 & $\mathrm{D}$ \\
\hline 13 & Lack of stable power supply for warming pens & 3.88 & 0.49 & A \\
\hline 14 & Lack of storage facilities & 3.92 & 0.77 & A \\
\hline 15 & Fragility of poultry products such as eggs and day old chicks & 4.57 & 0.64 & A \\
\hline 16 & Stampede in poultry & 2.38 & 0.52 & $\mathrm{D}$ \\
\hline 17 & High cost of labour & 4.00 & 0.63 & A \\
\hline 18 & Poor technical know-how of improved farming technologies & 4.32 & 0.52 & A \\
\hline 19 & Inadequate credit facilities for improved production & 4.20 & 0.52 & A \\
\hline 20 & Lack of information on improved technology in poultry & 3.84 & 0.72 & A \\
\hline 21 & Inadequate space for expansion of poultry business & 2.58 & 0.81 & $\mathrm{D}$ \\
\hline 22 & Inadequate institutional support from government & 2.78 & 0.82 & $\mathrm{D}$ \\
\hline
\end{tabular}

Note: $X=\bar{M}$ ean, $S D=$ Standard Deviation, $A=$ Agree, $D=$ Disagree

Source: Field Survey, 2016

Table 2: Mean ratings of the risk management strategies practiced by poultry farmers in the study Area $(\mathrm{n}=120)$

\begin{tabular}{clccc}
\hline SN & $\begin{array}{l}\text { Risk Management } \\
\text { Practices }\end{array}$ & X & SD & $\begin{array}{c}\text { Remar } \\
\mathrm{ks}\end{array}$ \\
\hline 1 & Enterprise diversification & 3.30 & 0.68 & $\mathrm{~A}$ \\
2 & Insurance & 2.05 & 0.90 & $\mathrm{D}$ \\
3 & Marketing strategies & 3.98 & 0.71 & $\mathrm{~A}$ \\
4 & Financial strategies & 2.43 & 0.87 & $\mathrm{D}$ \\
5 & Production strategies & 4.35 & 0.53 & $\mathrm{~A}$ \\
6 & Risks coping & 2.42 & 0.89 & $\mathrm{D}$ \\
\hline Note: $:$ X $\overline{\text { Mean, } \text { SD }=\text { Standard Deviation, A Agree, D }}$ \\
= Disagree \\
Source: Field Survey, 2016
\end{tabular}

Risk Management Strategies Practiced by the Poultry Farmers

The result in Table 2 presents the risk management strategies practiced by poultry farmers in Ekiti State. The result in the Table 2 showed that enterprise diversification has a mean value of 3.30, while marketing strategies and production strategies have mean values of 3.98 and 4.35 respectively. The mean values of these identified strategies are in each case greater that the cut-off point value of 3.00 on 5-point rating scale. This indicated that enterprise diversification, marketing and production strategies are practiced by the poultry farmers for managing associated risks in poultry farming activities in the state. In affirmation, Miranda (2002) however stated that most farmers combined production, financial and marketing responses in tackling farming risk. Kindre (2006) reported that enterprise diversification has the tendency for improving farmers' income to offset any negative influence of risk. On the hand, the mean values of insurance strategies was 2.05 while that of financial and risk coping strategies were 2.43 and 2.42 respectively. The mean values of the items are in each case less than the cut-off point value of 3.00 on 5-point rating scale. This indicates that insurance, financial and risk coping strategies are not utilized by farmers for risk management in the poultry farming enterprise in the state. Ajieh, (2010) stated that farm insurance is one good way of minimizing this problem of natural hazards, although, farmers in this area of study are yet to fully access insurance adequately.

\section{Determinants of Poultry Farmers' Output}

Table 3 presents the results of the regression analysis and it shows that the semi-log functional form had the best fit, based on the values of $\mathrm{R}^{2}$ (0.967), number and levels of significance of explanatory variables and their signs. The F-value of (241.136) indicated that the overall equation was highly significant at $(\mathrm{p}<0.01)$ while Durbin-Watson (DW) of 2.210 showed the absence of autocorrelation these were age, household size, education, stock size, capital input, farming experience, location, cost of feed, cost of medication, cost of labour and risk index. Age of the farmers was significant and positively affected their poultry farming output at $\mathrm{p}<0.01$. This suggests that as the age of the poultry farmers increase, their output in poultry farming increase. The coefficient of the household size was significant $(\mathrm{p}<0.01)$ but negatively affected poultry farm output of the farmers. 
Table 3 : Determinants of farmer's output in poultry farming enterprise in Ekiti State.

\begin{tabular}{|c|c|c|c|c|}
\hline Variables & Linear & Semi $\log \{a\}$ & Double $\log$ & Exponential \\
\hline Age $\left(X_{1}\right)$ & $\begin{array}{l}78.327 \\
(7.127)^{* * *}\end{array}$ & $\begin{array}{l}3.098 \\
(8.159) * * *\end{array}$ & $\begin{array}{l}0.404 \\
(4.245)^{* * *}\end{array}$ & $\begin{array}{l}6.092 \\
(6.148) * * *\end{array}$ \\
\hline Gender $\left(\mathrm{X}_{2}\right)$ & $\begin{array}{l}1.747 \\
(0.483)\end{array}$ & $\begin{array}{l}0.102 \\
(0.083)\end{array}$ & $\begin{array}{l}-0.001 \\
(-0.377)\end{array}$ & $\begin{array}{l}111.242 \\
(0.489)\end{array}$ \\
\hline Household Size $\left(X_{3}\right)$ & $\begin{array}{l}150.539 \\
(5.855)^{* * *}\end{array}$ & $\begin{array}{l}-0.029 \\
(-6.058) * * *\end{array}$ & $\begin{array}{l}-0.087 \\
(-0.951)\end{array}$ & $\begin{array}{l}-3.911 \\
(-6.903) * * *\end{array}$ \\
\hline Years of Education $\left(\mathrm{X}_{4}\right)$ & $\begin{array}{l}327.070 \\
(2.185)^{* *}\end{array}$ & $\begin{array}{l}1.054 \\
(2.064) * *\end{array}$ & $\begin{array}{l}0.008 \\
(1.45)\end{array}$ & $\begin{array}{l}139.888 \\
(1.637)\end{array}$ \\
\hline Primary Occupation $\left(\mathrm{X}_{5}\right)$ & $\begin{array}{l}-0.865 \\
(-4.679) * * *\end{array}$ & $\begin{array}{l}0.018 \\
(0.551)\end{array}$ & $\begin{array}{l}-0.025 \\
(-2.133)^{* *}\end{array}$ & $\begin{array}{l}-19.950 \\
(-5.338)^{* * *}\end{array}$ \\
\hline Stock Size $\left(\mathrm{X}_{6}\right)$ & $\begin{array}{l}76.249 \\
(8.898)^{* * * *}\end{array}$ & $\begin{array}{l}0.819 \\
(4.028) * * *\end{array}$ & $\begin{array}{l}0.153 \\
(1.264)\end{array}$ & $\begin{array}{l}4.794 \\
(8.296)^{* * * *}\end{array}$ \\
\hline Capital Input $\left(\mathrm{X}_{7}\right)$ & $\begin{array}{l}1.264 \\
(4.697)^{* * * *}\end{array}$ & $\begin{array}{l}9.006 \\
(6.570)^{* * * *}\end{array}$ & $\begin{array}{l}1.062 \\
(6.997)^{* * *}\end{array}$ & $\begin{array}{l}415.438 \\
(3.043)^{* * *}\end{array}$ \\
\hline Farming Experience $\left(\mathrm{X}_{8}\right)$ & $\begin{array}{l}5.531 \\
(3.098) * * *\end{array}$ & $\begin{array}{l}0.019 \\
(3.121)^{* * *}\end{array}$ & $\begin{array}{l}0.342 \\
(3.560) * * *\end{array}$ & $\begin{array}{l}21.780 \\
(5.167)^{* * *}\end{array}$ \\
\hline $\begin{array}{l}\text { Membership } \\
\text { of Cooperative }\left(\mathrm{X}_{9}\right)\end{array}$ & $\begin{array}{l}-3.321 \\
(-0.893)\end{array}$ & $\begin{array}{l}0.209 \\
(0.376)\end{array}$ & $\begin{array}{l}0.005 \\
(1.374)\end{array}$ & $\begin{array}{l}0.117 \\
(0.993)\end{array}$ \\
\hline Location $\left(\mathrm{X}_{10}\right)$ & $\begin{array}{l}1.894 \\
(1.837)^{*}\end{array}$ & $\begin{array}{l}0.199 \\
(3.987) * * *\end{array}$ & $\begin{array}{l}-0.001 \\
(-0.242)\end{array}$ & $\begin{array}{l}-1.070 \\
(-1.466)\end{array}$ \\
\hline Cost of Feed $\left(\mathrm{X}_{11}\right)$ & $\begin{array}{l}0.304 \\
(0.850)\end{array}$ & $\begin{array}{l}-5.665 \\
(-2.285)^{* *}\end{array}$ & $\begin{array}{l}-0.361 \\
(3.248)^{* * * *}\end{array}$ & $\begin{array}{l}658.636 \\
(0.363)\end{array}$ \\
\hline Cost of Medication $\left(\mathrm{X}_{12}\right)$ & $\begin{array}{l}-12.736 \\
(-3.571)^{* * *}\end{array}$ & $\begin{array}{l}-3.440 \\
(-5.696)^{* * *}\end{array}$ & $\begin{array}{l}-0.433 \\
(-4.657)^{* * *}\end{array}$ & $\begin{array}{l}-600.290 \\
(-4.415)^{* * * *}\end{array}$ \\
\hline Cost of Labour $\left(\mathrm{X}_{13}\right)$ & $\begin{array}{l}18.004 \\
(6.410)^{* * * *}\end{array}$ & $\begin{array}{l}6.545 \\
(3.122) * * *\end{array}$ & $\begin{array}{l}0.686 \\
(4.144) * * *\end{array}$ & $\begin{array}{l}843.861 \\
(5.137)^{* * *}\end{array}$ \\
\hline Risk Index $\left(\mathrm{X}_{14}\right)$ & $\begin{array}{l}-4.044 \\
(-1.031)\end{array}$ & $\begin{array}{l}-0.094 \\
(-2.474) * *\end{array}$ & $\begin{array}{l}-0.141 \\
(-1.594)\end{array}$ & $\begin{array}{l}1.698 \\
(0.361)\end{array}$ \\
\hline COSTANT & $\begin{array}{l}358.491 \\
(6.491)^{* * *}\end{array}$ & $\begin{array}{l}9.820 \\
(10.884)^{* * * *}\end{array}$ & $\begin{array}{l}-0.210 \\
(-5.714)\end{array}$ & $\begin{array}{l}-43.462 \\
(-3.537)^{* * * *}\end{array}$ \\
\hline $\mathrm{R}^{2}$ & 0.944 & 0.964 & 0.933 & 0.915 \\
\hline Adjusted $\mathrm{R}^{2}$ & 0.932 & 0.953 & 0.930 & 0.907 \\
\hline F-Value & 228.602 & 241.136 & 230.795 & 116.592 \\
\hline Durbin-Watson (DW) & 1.995 & 2.210 & 2.317 & 2.064 \\
\hline Observation & 120 & 120 & 120 & 120 \\
\hline
\end{tabular}

This implies that increase in household size reduces the output of the poultry farmers. The negative relationship between household size and output of farmers in naira may result from the fact that part of products that would have been sold for money are consumed by members of the households. This finding disagreed with that of Amusa, Enete and Okon (2011) where the authors found that household size significantly and positively affected output of cocoyam farmers. Years of education of the farmers was significant $(\mathrm{p}<0.05)$ and positively related with their poultry farm output. This conformed with a priori expectation as increase in education is expected to increase the mastery and expertise of the poultry farmers for increased output. The findings of this study is in support of that of Bukunmi and Yusuf (2015) who found that years of education was positive and significantly influence poultry egg production in Ondo State. Alabi and Aruna (2006) reported that level of education determines the quality of skills of farmers, their allocative abilities and how well informed they are to the innovations and technologies around them. The coefficient of stock size was highly significant $(\mathrm{p}<0.05)$ and positively related with poultry farm output. This is expected as increase in number of birds should result into a corresponding increase in farm output, all things being equal. The findings of this study corroborated that of Yusuf, Tiamiyu and Aliu (2016) where the authors found that stock capacity significantly and positively affected farm revenue. In agreement with this result, Nurudeen (2012), Yusuf and Malomo (2007) explained that stock capacity stands for the number of birds in the farm and farm revenue increases with number of flocks. The coefficient of capital input into poultry farming was significant $(\mathrm{p}<0.05)$ and positively related with output. This suggests that as the farmers increase capital input into their poultry farms as investment, there is increase in output. The findings of this study corroborated that of Bukunmi and Yusuf (2015) who in a similar study found that farmers access to credit (capital) significantly and positively influence poultry egg production. This is probably because availability of adequate capital input to finance and expand farm operations will in turn result into improved productivity and farm output. Farmers' years of farming experience in poultry farming was highly significant $(\mathrm{p}<0.01)$ and 
Obike, K.C. Amusa, T.A. and Olowolafe, H.B.

positively correlated with output. The positive and significant relationship is indicates that farmers with high years of farming experience are likely to attract more output that farmers with low experience. This conformed with a priori expectation. The finding of this study is in line with the result of the study of Effiong, Enyenihi and George (2014) who in a study found that there is positive relationship between farming experience and poultry farm output. Farming involves a lot of risks and uncertainties; therefore to be competent enough to handle all the vagaries of agriculture, farmers must have stayed in farming business for quite some time (Ogundele and Okoruwa, 2006). The coefficient of location ( 1 if urban, 0 otherwise) was positive and significantly related to poultry farm output at $p<0.01$. The positive relationship indicates that poultry farmers in urban areas have higher output in poultry farming than their counterparts in rural areas. This is expected as the steadily high demand for poultry products in urban areas is capable of increasing the output of the poultry farmers in urban than rural areas.

Cost of feed for poultry birds was significant $(p<0.05)$ but negatively related with output of poultry farmers in the study area. This indicates that an increase in cost of feed will result to decrease in the output of poultry farmers. The coefficient of cost of medication was also negative and significantly related with output of poultry farmers. Cost of labour was highly significant at $\mathrm{p}<0.05$ and positively correlated with output of poultry farmers. The positive relationship between labour cost and output suggests that as farmers pay more on labour, there is increase in output. In this case, the increase in labour cost may indicate hiring of more labourers resulting in higher output. The findings of this study conformed to that result of Yusuf, Tiamiyu and Aliu (2016) who investigated financial analysis of poultry production in Kwara State and found that operating cost (TVC) which may include cost of feed, medication, labour among others significantly influence revenue. The coefficient of risk index was significant $(p<0.05)$ but negatively related with output of poultry farmers. This conforms with a priori expectation as outputs of farmers are likely to be negatively affected by the number of risks encountered in their farming activities.

\section{CONCLUSION AND RECOMMENDATIONS}

Risk is an inherent feature of modern poultry production due to the complex and fragile nature of poultry products. In Nigeria and Ekiti State in particular, the production activities of poultry farmers are characterized by high level of risks. Theft of birds, price fluctuation, and other forms of threats and uncertainty force some farmers to sell off their products below production costs. This leads to reduction in profit, capital investment and low savings of the poultry farmers among others. Based on the background that this study was carried out to investigate risk management and determinants of farm output among small scale poultry farmers in Ekiti State, Nigeria. The study concludes that production, financial, marketing, technological and human risks are the major sources of risks encountered by poultry farmers. Frequent cases of disease outbreak, high cost of medication and vaccines, insufficient fund, lack of quality feed and fragility of poultry products are some of the risk situations in poultry farming in the study area. Enterprise diversification, marketing and production strategies are the common risk management practices among the poultry farmers. Socioeconomic variables such as age, household size, education, stock size, capital input, farming experience, location, cost of feed, cost of medication, cost of labour and risk index significantly influenced output of the poultry farmers.

Based on the above findings, the study recommended that:

1. Small scale poultry farmers should be encouraged by government, non-governmental organizations and development agencies to diversify into other viable income generating activities to increase output and reduce shock of failure,

2. There should be organization of trainings and seminars for poultry farmers in the effective risk management practices for maximum output,

3. There should be adequate institutional support in form of credits facilities, sales of day old chicks, quality feed, vaccines and drugs in government stores to poultry farmers for improved productivity.

\section{REFERENCES}

Abotsi, A. K., Dake, G. Y and Agyepong, R. A. (2014). Factors Influencing Risk Management Decision of Small and Medium Scale Enterprises in Ghana. Contemporary Economics, 8: (4): 397 - 414.

Adepoju, A. O., Timothy, O. A and Oyekale, A. S. (2013). Risk Coping Behaviour of Small Scale Poultry farmers in Ogun State, Nigeria. Asian Journal of Animal and Veterinary Advances, 8: 786 $-795$.

Adubi, A. A. (2000). The Economic Behaviour of Nigeria Small Scale Farmer. Implication for Food Policy in the 1990's. Discovery Innovation, 12: 199 -202 . 
Risk Management and Determinants of Farm Output Among Small Scale Poultry Farmers

Ajieh. P. C. (2010). Poultry Farmers Response to Agricultural Insurance in Delta State. Nigerian Journal of Agric. Sc. 1 (1): 43- 47.

Akinola, B. D. (2014). Risk Preferences and Coping Strategies among Poultry Farmers in Abeokuta Metropolis, Nigeria. Global Journal of Science Frontier Research: D Agriculture and Veterinary, 14 (5): $22-30$.

Alabi, R. A and Aruna, M. B. (2006). Technical Efficiency of Family Poultry Production in Niger Delta, Nigeria. Journal Central European Agriculture, 6 (4): 531 - 538.

Alimi, T and Ayanwale, A. B. (2005). Risk and Risk Management Strategies in Onion Production in Kebbi State of Nigeria. J. Soc. Sci., 10 (1): 1-8.

Amusa, T. A; Enete, A. A and Okon, U. E. (2011). Socio-economic Determinants of Cocoyam Production among Small Holders Farmers in Ekiti State, Nigeria. International Journal of Agricultural Economics and Rural Development. 4 (2): 97-109.

Asogwa, B. C., Abu, O and Ogene, A. (2014). Agricultural Risk Management and Production Efficiency among Peasant Farmers in Benue State, Nigeria. Asian Journal of Agricultural Extension, Economics \& Sociology, 3(5): 373-391.

Bamiro, O. M., Momoh, S and Phillip, D. O. A. (2009). Vertical Integration and Profitability in Poultry Industry in Ogun and Oyo States, Nigeria. $J$. Human Ecol., 27: 149 - 154.

Bukunmi, F. R and Yusuf, H. A. (2015). Analysis of Socio-Economic Factors Influencing Poultry Egg Production among Poultry Farmers in Ondo State, Nigeria. British Journal of Applied Science \& Technology, 10 (3): $1-7$.

Effiong, E. O., Enyenihi, E. A and George, A. A. (2014). Analysis of Farming Risk among Small Scale Poultry Farmers in Etim Ekpo Local Government Area of Akwa Ibom State, Nigeria. Nigerian Journal of Agriculture, Food and Environment, 10 (1): $59-64$.

Ekiti State Government, (2008). The People of Ekiti State. Retrieved August 13, 2016 from http://www.ekitinigeria.net/

Fakayode, B. S., Ometesho, O. A., Tsoho, A. B and Ajayi, P. P. (2008). An Economics Survey of Rural Infrastructure and Agricultural Productivity Profile in Nigeria. European Journal of Social Science, 7 (2): 158-171.

FAO (2010). Chicken Genetic Resources Used in Smallholder Production Systems and Opportunities for their Development. FAO Smallholder Poultry Production Paper, No. 5. Rome: Food and Agriculture Organisation.

FAO. (2013). The State of Food Insecurity in the World: The Multiple Dimensions of Food Security. Rome: Food and Agriculture Organisation.

Howell, J. B and Hazzard, R. V. (2012). Risk Management and Crop Insurance for New England Vegetable Grower. Willoughby: Meister Publishing Company.

Jain, R. C and Parshad, M. (2007). The Report of the Working Group on Risk Management in
Agriculture". New Delhi: Government of Indian Planning Commission.

Joseph, J. K, Ajayi, S. (2002). Agricultural Products and Man. History and Philosophy of Science: General Studies Approach: Akanji MA, Jolayemi ET (Eds.). 118 - 141.

Kindre, T. P. (2006). Risk Assessment and its Role in the Safety of Foods of Animal Origin. $J$. Ame.Vet.Med. Assoc., 209: 2055 - 2058. s

Lawal, B. O., Torimiro, D. O and Makanjuola, B. A.(2009). Impact of Agricultural Extension Practices on the Nigerian Poultry Farmers' Standard of Living: A Perceptional Analysis. Tropical and Subtropical Agroecosystems, 10: 465-473.

Miranda, M. J. (2002). Area Yield Crop Insurance Reconsidered. American Journal of Agricultural Economics. 73: 233-236.

National Bureau of Statistics, (2012). Annual Abstract of Statistics, 2012. Abuja: National Bureau of Statistics.

Njavro M (2009). Risk Management in Agribusiness. Paper Presented at Zagreb School of Economics and Management, June 5, 2009.

Nurudeen, A. J. (2012). Economics and social characteristics of registered poultry egg producers in Ilorin, Kwara state. Russian J. Agric. SocioEcon. Sci. 11: 11.

Obike, K.C., Ebe, F.E and Onu, D.O (2016). Technical Efficiency of Crop-Farmers Subscribers of National Agricultural Insurance Cooperation (NAIC) in Ehime Mbano Local Government Area of Imo State, Nigeria. Nigerian Journal of Agriculture, Food and Environment 12(2): 149155.

Ogundele, O. O. and V. O. Okoruwa. (2006). Technical Efficiency Differentials in Rice Production Technologies in Nigeria. AERC Research Paper 154, Nairobi, Kenya. Retrieved October 10, 2016 from http://www.aecrafrica.org/documents/

Olarinde, L. O., Manyong, V. M and Akintola, J. O. (2010). Factors Influencing Risk Aversion among Maize Farmers in the Northern Guinea Savanna of Nigeria: Implications for Sustainable Crop Development Programmes. Journal of Food, Agriculture \& Environment, 8 (1): 128 - 134.

Oparinde, A. O. (2008). Economics and Livelihood Impacts of HPAI. Proceedings of the Pro-Poor HPAI Reduction Strategies, Multi-Stakehloder Workshop, June 17, 2008, Nigeria.

Vanany, I., Zailani, S and Pujawan, N. (2009). Supply Chain Risk Management: Literature Review and Future Research. International Journal of Information Systems and Supply Chain Management, 2 (1): 16 - 33.

Yusuf, S. A and Malomo, O. (2007). Technical Efficiency of Poultry Egg Production in Ogun State: A Data Envelopment Analysis (DEA) approach. Int. J. Poult. Sci. 6 (9): 627 - 629.

Yusuf, T. M., Tiamiyu, S. A and Aliu, R. O. (2016). Financial analysis of poultry production in Kwara State, Nigeria. African Journal of Agricultural Research, 11 (8): 718-723. 